\title{
REVIEW
}

Open Access

\section{Phytochemistry and therapeutic potential of black pepper [Piper nigrum (L.)] essential oil and piperine: a review}

Kaliyaperumal Ashokkumar ${ }^{1 *}$, Muthusamy Murugan ${ }^{1}$, M. K. Dhanya ${ }^{1}$, Arjun Pandian $^{2}$ and Thomas D. Warkentin ${ }^{3}$

\begin{abstract}
Background: Black pepper [Piper nigrum (L.), Family: Piperaceae] is used traditionally for the treatment of various diseases including; cough, cold, dyspnea throat diseases, intermittent fever, dysentery, stomachache, worms and piles. The pharmacological potential of black pepper is due to the presence of metabolites like phenolic compounds, alkaloids, flavonoids, carotenoids, terpenoids, etc. The multipurpose use of black pepper dried seeds has several other beneficial health effects that also received in the light of traditional as well as current medicine perspectives. The review aims to discuss the botany, phytochemical constituents, and pharmacological properties of piperine and black pepper essential oil (BPEO).

Results: Phytochemical analyses have described the main chemical constituents of black pepper, including carbohydrates, proteins, calcium, magnesium, potassium, iron, vitamin C, tannins, flavonoids and carotenoids. The volatile oil content ranges from 0.4 to $7 \%$ in dried berries. The major constituents of BPEO are sabinene, 3-carene, D-limonene, a-pinene, caryophyllene, $\beta$-phellandrene, a-phellandrene, a-thujene, and $\beta$-bisabolene. Additionally, piperine is the naturally occurring and principal bioactive alkaloid constituent of black pepper owing to its potential therapeutic properties, including cerebral brain functioning and increased nutrient absorption. The BPEO has several biological roles, including antioxidant, anti-inflammatory, anticancer, anti-obesity, antidepressant, antidiabetic, antimicrobial, gastroprotective, and insecticidal activities.

Conclusions: This review examines and presents the appropriate evidence on black pepper and its traditional uses as well as biological activities of BPEO and piperine. Although several previous reports showed diverse biological effects for piperine and bioactive constitutes of BPEO. Thus, minimal investigations were conducted using animal models, and many of these studies also lacked appropriate experimental setting like doses, control details. Hence, future studies are necessary to understand the mechanism of piperine, BPEO, bioactive constituents and their effects upon their use by animal models and humans with the proper experimental procedure which we can facilitate the protection of human health from several diseases.
\end{abstract}

Keywords: Piper nigrum, Botany, Phytochemistry, Essential oil, Piperine, Pharmacological applications

\footnotetext{
*Correspondence: biotech.ashok@gmail.com

${ }^{1}$ Cardamom Research Station, Kerala Agricultural University, Pampadumpara,

Kerala 685553 Idukki, India

Full list of author information is available at the end of the article
}

\section{Springer Open}

(c) The Author(s). 2021 Open Access This article is licensed under a Creative Commons Attribution 4.0 International License, which permits use, sharing, adaptation, distribution and reproduction in any medium or format, as long as you give appropriate credit to the original author(s) and the source, provide a link to the Creative Commons licence, and indicate if changes were made. The images or other third party material in this article are included in the article's Creative Commons licence, unless indicated otherwise in a credit line to the material. If material is not included in the article's Creative Commons licence and your intended use is not permitted by statutory regulation or exceeds the permitted use, you will need to obtain permission directly from the copyright holder. To view a copy of this licence, visit http://creativecommons.org/licenses/by/4.0/. 


\section{Background}

Black pepper (Piper nigrum L.) commonly known as the "King of Spices", belonging to the family Piperaceae, is one of the most popular spices used worldwide and is native to southern India [1]. The name "pepper" originated from the Sanskrit word "Pipali", and other Indian vernacular names are Milagu (Tamil), Kari Menasu (Kannada), Kuru Mulagu (Malayalam), Miriyam (Telugu), and Kali Mirch (Hindi). Most of the production of black pepper occurs in India, Malaysia, Indonesia, China, Thailand, Sri Lanka, Vietnam, Brazil and Madagascar [2]. Black pepper is one of the vital spicy ingredients in foods, especially in Asian countries, and it also possesses potential applications in traditional medicine, perfumery, preservatives and insecticides [3].

Plant-based food products are storehouses of several bioactive constituents such as phenolics, flavonoids [49], terpenes [10] and sterols [11]. These constituents have been evaluated for their biological and antibacterial effects [12, 13]. In traditional medicines, black pepper has been reported to have a gastrointestinal activity to increase appetite, to antidote cough, cold, dyspnea throat diseases, discontinuous fever, dysentery, stomachache, worms and piles [14] and is used as anti-inflammatory, antipyretic, and to treat epilepsy and snakebite [15-17].

The aroma and pungency of black pepper are mainly attributed to piperine and volatile oils [18]. Piperine is the major bioactive component in black pepper, and its displays various therapeutic benefits including antiplatelet, antihypertensive [19], anticancer, antioxidant [20], analgesic, antidepressants and anti-diarrheal [21]. The alkaloid piperine improves the therapeutic value of several drugs, vaccines and nutrients by enhancing bioavailability through inhibiting numerous digestive enzymes [22]. Likewise, piperine aids in digestion through stimulating pancreatic and intestinal enzymes, and enriches cognitive skills and fertility [22, 23]. Furthermore, piperine is recognized as delivering several therapeutic activities distinct from other chemical components [2].

Black pepper essential oil constitutes approximately $0.4-7 \%$ of the berry dry weight [24] and is beneficial for the management of rheumatism, cold, tiredness, muscular pains and infection. It was also used as a nerve stimulant to enhance blood circulation [24, 25]. Both white pepper and black pepper contained $2-7 \%$ piperine $[24,26]$. The volatile oil constituent piperamides and nerolidol exhibited insecticidal activities [27, 28]. $\beta$ caryophyllene displayed anaesthetic effects, and piperine was used in perfumes [29]. Black pepper has been used for millennia, including plant breeding activities for the development of superior varieties with improved organoleptic and nutritional properties. It has been used in traditional as well as modern medicine. This review aims to highlight the main phytochemicals and therapeutic effects of Piper nigrum (L.) essential oil and piperine related to human health.

\section{Botanical description}

Black pepper (Piper nigrum L.) belongs to the family Piperaceae. The basic chromosome number $\mathrm{x}=13$ and $2 n=52$ indicates its balanced tetraploid nature. Nevertheless, no species with a diploid number $(2=26)$ has been stated from India [30]. According to Ravindran [31] morphological and biosystematics studies, three species P. wightii, P. trichostchyon and P. galeatum are the putative parents for $P$. nigrum. Black pepper is a perennial climbing vine that grows well in the shade with supporting trees or poles. The glabrous woody climbers grow up to $10 \mathrm{~m}$ or more height [32]. Black pepper plant has 10-20 primary adventitious roots developed from the base of the mature stem [32]. The vines are grown dimorphic branching (monopodial, orthotropic branches and sympodial, plagiotropic fruiting branches) pattern. The orthotropic shoot has indeterminate growth, and leaf axils produce lateral fruiting branches. Also, each node of the orthotropic shoot has clinging roots that help the plant climb over the support trees [33]. Leaves are simple, alternate, with 2 to $5 \mathrm{~cm}$ long grooved petiole, variable leaf length and breadth, 8-20 $\mathrm{cm}$ and 4$12 \mathrm{~cm}$ respectively [32]. In India, 2 to 3 years after planting black pepper plants have flowering during south-east monsoon (May - July). The fruiting spikes are varied lengths $(3-15 \mathrm{~cm})$. After 10-15 days spike emergence, the first flower appears on the top of the spike and completed nearly 6-10 days. The inflorescence is glabrous; pendulous spike arises opposite to leaves on plagiotropic branches [34]. Wild type flowers are mostly dioecious, but the cultivated type flowers are monoecious. Selfpollination is predominant, and protogyny also encountered in black pepper [35]. The matured fruits are spherical in shape $(\sim 5 \mathrm{~mm}$ diameter $)$ and belong to drupe type. The harvested fruits are sun-dried for further use. A typical photograph of the field view and various botanical features of including such as habitat, spikes, matured and dried berries (seeds) are presented in Fig. 1.

\section{Chemical composition}

Proximate, minerals, vitamins and bioactive metabolites

Black pepper is rich in minerals, vitamins and nutrients. The chemical composition of $100 \mathrm{~g}$ of black pepper seeds includes carbohydrate $66.5 \mathrm{~g}$, protein $10 \mathrm{~g}$, and fat $10.2 \mathrm{~g}$ [36], as well as a relatively high concentration of minerals such as calcium (400 mg), magnesium (235.8$249.8 \mathrm{mg}$ ), potassium (1200 mg), phosphorus (160 mg), and the lower concentration of sodium, iron and zinc [36, 37]. These minerals are essential elements for dayto-day activities of humans. Besides, black pepper also has a significant concentration of vitamins such as 


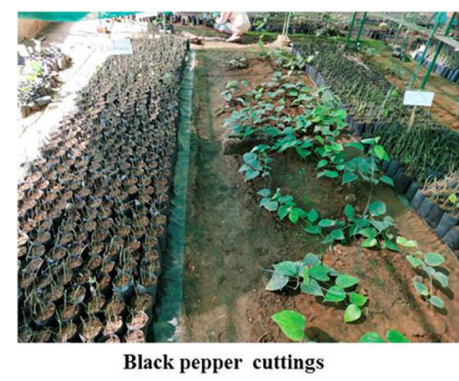

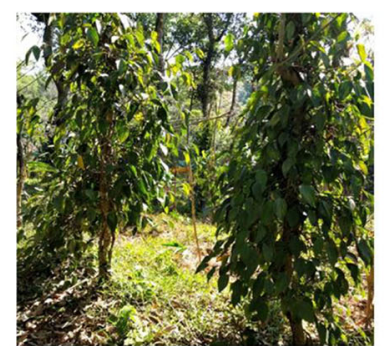

Field view

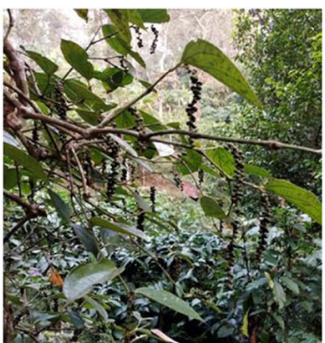

Twig with spikes
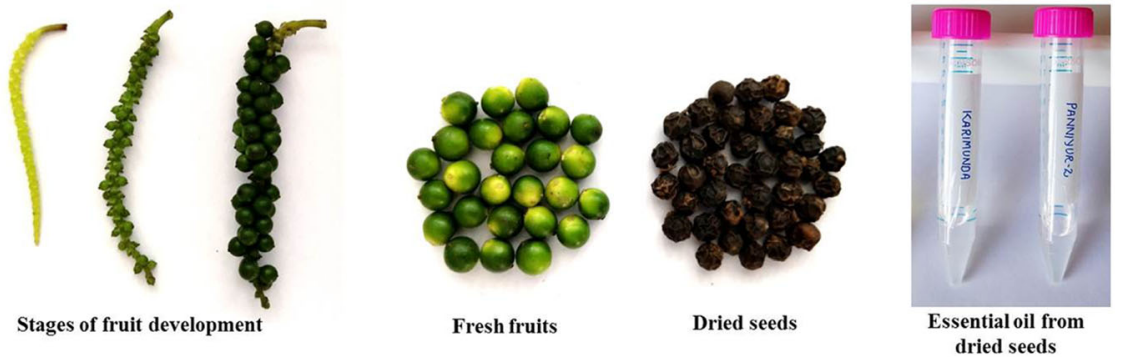

Fig. 1 Field view and botanical features of Black pepper (P. nigrum L.)

Vitamin C, B1, B2 and B3 (Table 1). Nine accessions of Nigeria grown black pepper had a concentration of tannin ranging from 2.11 to $2.80 \mathrm{mg} / 100 \mathrm{~g}$ [37]. In a recent study on black pepper, Ashokkumar et al. 10 reported flavonoids such as catechin, quercetin and myricetin, and carotenoids, namely lutein and $\beta$-carotene was detected in significant concentration (Table 1).

\section{Essential oil, Oleoresin and Piperine}

Several researchers evaluated essential oils (EO), oleoresin and piperine in various parts of black pepper (Table 2). The EO yield of black pepper berries and leaves have varied from 1.24 to $5.06 \%$, and $0.15-0.35 \%$, respectively [39-41]. However, the oil yield depends on the variety, area and age of the product, parts and methods used (Table 2). Kurian et al. [39] observed variability of volatile oil and oleoresin content in 14 black pepper accessions ranging from $2.7-5.1 \%$ and $7.6-$ $9.4 \%$, respectively. These researchers reported that volatile oil content was positively correlated with oleoresin and suggested concurrent improvement of these characters by simple selection programme is the best tool for improvement of quality traits in black pepper. Kurian et al. [39] also reported classical hydro-distillation as a better method of volatile oil estimation compared to other techniques (Table 2). The oleoresin content of black pepper ranged between 4.27 and $12.73 \%$ [38, 42], and the characteristic natural alkaloid of black pepper "piperine" ranged from $2.13-5.80 \%$ and $0.12-20.86 \%$, in seeds and leaves correspondingly (Table 2).
The EO profile of black pepper seeds from south India is predominately comprised of $\beta$-caryophyllene followed by limonene, sabinene, $\alpha$-pinene, $\beta$-bisabolene, $\alpha$ copaene $\alpha$-cadinol, $\alpha$-thujene, $\alpha$-humulene; pepper leaves were rich in nerolidol followed by $\alpha$-pinene and $\beta$-caryophyllene $[38,41]$ (Table 3). Likewise seeds from Bangladesh were contained EO consisting of $\beta$ caryophyllene $(18.39 \%)$ followed by $\alpha$-pinene $(16.68 \%)$, limonene $(16.16 \%), \quad \beta$-pinene $(13.61 \%), \delta$-3-carene (9.23\%), $\beta$-phellandrene $(3.16 \%)$, copaene $(3.13 \%)$, 1napthalenol (3.0\%), and $\beta$-myrcene (2.89\%) [45]. EO of seeds from Sri Lanka, Malaysia, and Brazil showed some noticeable variations in major metabolites (Table 3). The molecular structures of major essential oil constituents isolated from pepper seeds and leaves were drawn by ChemDraw software and are shown in Fig. 2. The yield of minor EO of black pepper contained $\beta$-Elemene $(1.74 \%), \delta$-Elemene $(0.60 \%), \alpha$-Cubebene $(0.99 \%), \alpha$ Guaiene $(0.36 \%), \quad \alpha$-Zingiberene $(0.74 \%), \quad$-Cymene $(0.70 \%), \quad$ Bicyclogermacrene $\quad(0.31 \%), \quad \gamma$-Cadinene $(0.65 \%), \quad \gamma$-trans-Bisabolene $\quad(1.39 \%), \quad$ Hedycaryol (0.37\%), and Germacrene D (0.22\%) [46].

\section{Pharmacological and biological effects of BPEO and piperine}

The piperine, BPEO and its active constituents have a number of potential biological activities, including antioxidant, antimicrobial, antitumour, cytotoxicity, and miscellaneous activities that are summarized in Table 4. The potential biological activities of BPEO and piperine were diagrammatically presented in Fig. 3. 
Table 1 Nutritional composition of $100 \mathrm{~g}$ of black pepper

\begin{tabular}{|c|c|c|}
\hline Chemical composition & Concentration & References \\
\hline \multicolumn{3}{|l|}{ Proximate } \\
\hline Water (g) & 8.0 & {$[36]$} \\
\hline Energy (Kcal) & 400.0 & {$[36]$} \\
\hline Carbohydrate (g) & 66.5 & {$[36]$} \\
\hline Protein (g) & 10.0 & {$[36]$} \\
\hline Fat (g) & 10.2 & {$[36]$} \\
\hline Total Ash (\%) & $3.43-5.09$ & {$[38]$} \\
\hline Crude fibre (\%) & $10.79-18.60$ & {$[38]$} \\
\hline \multicolumn{3}{|l|}{ Minerals } \\
\hline Calcium (mg) & 400.0 & {$[36]$} \\
\hline Magnesium (mg) & $235.8-249.8$ & {$[37]$} \\
\hline Phosphorus (mg) & 160.0 & {$[36]$} \\
\hline Sodium (mg) & 10.0 & {$[36]$} \\
\hline Potassium (mg) & 1200.0 & {$[36]$} \\
\hline Iron (mg) & $17.0[36]$ & \\
\hline Zinc (mg) & $1.45-1.72$ & {$[37]$} \\
\hline \multicolumn{3}{|l|}{ Vitamins } \\
\hline Vitamin C (mg) & $27.46-32.53$ & {$[37]$} \\
\hline Vitamin B1 (mg) & $0.74-0.91$ & {$[37]$} \\
\hline Vitamin B2 (mg) & $0.48-0.61$ & {$[37]$} \\
\hline Vitamin B3 (mg) & $0.63-0.78$ & {$[37]$} \\
\hline \multicolumn{3}{|l|}{ Metabolites } \\
\hline Tannin (mg) & $2.11-2.80$ & {$[37]$} \\
\hline \multicolumn{3}{|l|}{ Flavonoids } \\
\hline Catechin $(\mu \mathrm{g})$ & 410.0 & {$[10]$} \\
\hline Myricetin $(\mu \mathrm{g})$ & 56.0 & {$[10]$} \\
\hline Quercetin $(\mu \mathrm{g})$ & 13.0 & {$[10]$} \\
\hline \multicolumn{3}{|l|}{ Carotenoids } \\
\hline Lutein $(\mu \mathrm{g})$ & 260.0 & {$[10]$} \\
\hline$\beta$-carotene $(\mu \mathrm{g})$ & 150.0 & {$[10]$} \\
\hline
\end{tabular}

\section{Antioxidant effects}

Oxidative stress is the main factor for initiation of various degenerative and chronic diseases, including cancer, immune dysfunction, diabetes and Parkinson's [63]. Antioxidants are natural or synthetic constituents that can be used for inhibition of free radical formation by scavenging and suppression of degenerative and chronic diseases [64]. A polyphenolic compound Hydroxytyrosol (HT), has a potent antioxidant effect on hydrogen donation and improved radical stability [65]. Supplementation with HT improves the white adipose tissue (WAT) dysfunction induced by high-fat diet (HDF) fed in mice through the modulation of transcription factors NF- $\mathrm{KB}$, Nrf2, SREBP-1c and PPAR- $\gamma$ as well as their target genes, involved in inflammation, antioxidant defences and lipogenesis [66, 67]. Vijayakumar et al. [68] noted that piperine has potential protection activity against lipid peroxidation and antioxidant activity in rats fed a high-fat diet which induced oxidative stress to cells. Piperine has greatest antioxidant potential and was utmost effective with minimum inhibitory concentration $(\mathrm{MIC})<325 \mathrm{mg} / \mathrm{ml}$ against all assessed gram positive and negative strains [69]. Under in vitro conditions, Jeena et al. [52] recorded that essential oil of black pepper scavenged superoxide, and inhibited tissue lipid peroxidation.

\section{Antibacterial and antimicrobial effects}

In general, consumers prefer natural and non-toxic products to protect foods from bacteria during storage. Because of the long-term usage of chemical preservatives, a resurgence of food pathogenic bacteria may occur, which can induce severe health problems in humans [70]. The antimicrobial activity of black pepper remains unclear till date. According to Rani et al. [71], piperine had potential antimicrobial as well as antifungal effects against Staphylococcus aureus, Bacillus subtilis, Escherichia coli, Aspergillus niger, (A) flavus, Alternaria alternata and Fusarium oxysporum. Phenolic compounds obtained from fresh black pepper seed extracts

Table 2 Yield of volatile oil, oleoresin and piperine from various parts of black pepper

\begin{tabular}{|c|c|c|c|c|c|}
\hline Parts & Volatile oil Extraction method & Volatile oil (\%) & Oleoresin (\%) & Piperine (\%) & References \\
\hline Seeds & Deep eutectic solvents (DESs) based microwave Hydrodistillation & 1.77 & - & - & [43] \\
\hline Seeds & Hydrodistillation & $2.66-5.06$ & 7.6-9.4 & - & [39] \\
\hline Seeds & Hydrodistillation & $1.60-2.80$ & $4.27-10.74$ & $2.62-5.50$ & [42] \\
\hline Seeds & Hydrodistillation & $1.60-3.20$ & $5.82-12.73$ & $2.13-4.49$ & [38] \\
\hline Seeds & Hydrodistillation & 1.24 & - & - & [40] \\
\hline Leaves & Hydrodistillation & $0.15-0.35$ & - & $0.12-20.86$ & [41] \\
\hline Seeds & Microwave assisted hydrodistillation & 1.45 & - & - & {$[40]$} \\
\hline Seeds & Supercritical fluid extraction & 1.70 & 10.60 & 5.80 & [44] \\
\hline
\end{tabular}


Table 3 Composition of major essential oils of Piper nigrum from various origins

\begin{tabular}{|c|c|c|c|c|}
\hline Origin & Parts & Constituents & Yield (\%) and references & \\
\hline \multirow[t]{9}{*}{ South India } & Seeds & $\beta$-caryophyllene & $9.52-26.95$ & {$[38]$} \\
\hline & & Limonene & $15.13-20.78$ & {$[2$} \\
\hline & & Sabinene & $0.00-19.23$ & {$[3$} \\
\hline & & a-pinene & $3.88-6.48$ & ; \\
\hline & & $\beta$-bisabolene & $1.32-7.96$ & {$[3$} \\
\hline & & a-humulene & $1.11-2.44$ & {$[3$} \\
\hline & & a-copaene & $0.20-5.51$ & \\
\hline & & a-cadinol & $0.18-4.89$ & 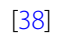 \\
\hline & & a-thujene & $0.60-2.94$ & {$[3$} \\
\hline \multirow[t]{3}{*}{ South India } & Leaves & Nerolidol & $0.14-66.32$ & \\
\hline & & a-pinene & $0.12-20.86$ & {$[4$} \\
\hline & & $\beta$-caryophyllene & $2.09-9.65$ & \\
\hline \multirow[t]{9}{*}{ Bangladesh } & Seeds & $\beta$-caryophyllene & 18.39 & {$[4$} \\
\hline & & a-pinene & 16.68 & {$[4$} \\
\hline & & Limonene & 16.16 & \\
\hline & & $\beta$-pinene & 13.61 & {$[4$} \\
\hline & & $\delta$-3-carene & 9.23 & {$[4$} \\
\hline & & $\beta$-phellandrene & 3.16 & \\
\hline & & Copaene & 3.13 & {$[4$} \\
\hline & & 1-napthalenol & 3.00 & {$[4$} \\
\hline & & $\beta$-myrcene & 2.89 & {$[4$} \\
\hline \multirow[t]{8}{*}{ Sri Lanka } & Seeds & $\beta$-caryophyllene & 12.5 & {$[4$} \\
\hline & & $\beta$-terpenine & 19.5 & {$[4$} \\
\hline & & Limonene & 19.2 & {$[4$} \\
\hline & & Sabinene & 19.2 & {$[4$} \\
\hline & & a-pinene & 11.2 & {$[4$} \\
\hline & & $\beta$-pinene & 12.1 & {$[4$} \\
\hline & & a $\beta$-phellandrene & 4.8 & {$[4$} \\
\hline & & Myrcene & 2.9 & {$[47$} \\
\hline \multirow[t]{8}{*}{ Malaysia } & Seeds & Limonene & 29.9 & {$[4$} \\
\hline & & $\beta$-pinene & 19.0 & {$[4$} \\
\hline & & $\beta$-caryophyllene & 14.0 & {$[4$} \\
\hline & & a-pinene & 7.3 & {$[4$} \\
\hline & & $\delta$-3-carene & 10.6 & {$[4$} \\
\hline & & Myrcene & 2.6 & {[} \\
\hline & & a-phellandrene & 2.2 & $l^{2}$ \\
\hline & & Linalool & 2.1 & {$[4$} \\
\hline \multirow[t]{6}{*}{ Brazil } & Seeds & $\delta$-3-carene & 55.43 & {$[4$} \\
\hline & & a-pinene & 16.25 & {$[4$} \\
\hline & & sylvestrene & 10.67 & [49] \\
\hline & & germacrene D & 2.17 & {$[49$} \\
\hline & & $\beta$-myrcene & 1.99 & [49] \\
\hline & & Isoterpinolene & 1.4 & {$[4$} \\
\hline
\end{tabular}

have the potential to inhibit the growth of Bacillus, Escherichia coli and Staphylococcus aureus, S. faecalis and $(B)$ cereus [72, 73]. Zhang et al. [74] showed that $1.0 \mu \mathrm{l} / \mathrm{ml}$ of BPEO was the effective minimum inhibition concentration against meat-borne $E$. coli, and suggested that black pepper essential oil has potential as a natural antibacterial agent in the meat industry. Similarly, BPEO displayed substantial activity against E. coli, B. substilis, and $S$. aureus [75]. Besides, most of the studies focusing on the antimicrobial effects of BPEO have been conducted disc diffusion method [71, 76, 77] though; given its intrinsic limitations, the technique requires to be improved through more relevant MIC assays [78].

\section{Anticancer effects}

The BPEO and piperine exert activities against several types of cancer (Table 4). Piperine significantly suppressed the tumour growth of both androgen-dependent and androgen-independent prostate cancer cells [79]. Makhov et al. [80] noted enhanced anticancer activity during co-administration of piperine and docetaxel in human prostate cancer. Additionally, piperine induced DNA damage and apoptosis in tumour cells and was a potential therapeutic agent for the treatment of osteosarcoma [81, 82]. Likewise, piperine reduced lung cancer by stimulation of antioxidative protective enzymes and through reducing lipid peroxidation [83]. Based on the above comments, piperine has potential anticancer activities. However, only a few studies have studied the antitumor potential of piperine and BPEO, and these were conducted in animal models only. Therefore, future studies should be attentive on the bioactivity of BPEO in several clinical investigations with humans.

\section{Cytotoxicity effects}

BPEO and piperine have good potential for augmenting the effectiveness of tumour necrosis factor (TNF) related apoptosis in breast cancer cells [84]. Greenshields et al. [85] reported that a combination of piperine and $\gamma$ radiation had higher cytotoxicity and effectiveness in stopping the growth of tripe negative cancer cells than radiation alone in immune-deficient mice. Although the safety of piperine and BPEO was showed, the use of cell lines only on in vitro assays confines the therapeutically relevance of this outcome.

\section{Insecticidal effects}

Black pepper possesses insecticidal activities against European chafer (Amphimallon majale, Coleoptera: Scarabaeidae) [27]. Upadhyay and Jaiswal [86], noticed that $0.2 \%$ concentration (v:v) of black pepper essential oil has potential repellent activity against adults of the major wheat grain storage pest Tribolium castaneum (Herbst). Naseem and Khan [28], stated that a higher 


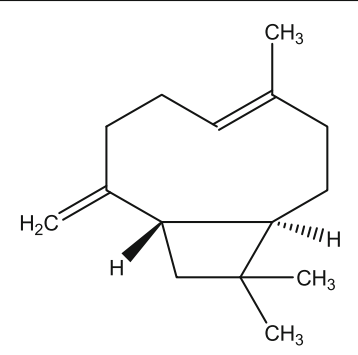<smiles>CC1=CCC2CC1C2(C)C</smiles><smiles>C=C1CCC2CC1C2(C)C</smiles><smiles>C=C(C)C1CC=C(C)CC1</smiles>

B-Caryophyllene

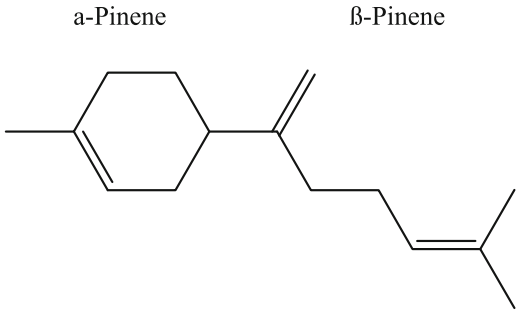

Limonene<smiles>C=C1CCC2(C(C)C)CC1C2</smiles>
Sabinene<smiles>C=CC(C)(O)CC/C=C(/C)CCC=C(C)C</smiles>

Nerolidol B-Bisabolene<smiles>C=C1CC=C(C(C)C)CC1</smiles><smiles>O=C(/C=C/C=C/c1ccc2c(c1)OCO2)N1CCCCC1</smiles>

Fig. 2 Molecular structures of piperine and major essential oil constituents from Piper nigrum (L.)

concentration of black pepper essential oil leads to maximum repellent effects at maximum exposure duration against $T$. castaneum. Thus far, only two studies have investigated the insecticidal effects of BPEO; therefore, further research needed in this promising application.

\section{Miscellaneous effects}

For centuries, black pepper has been used for traditional medicines to cure cuts and wound injuries. Piperine induced bioavailability of the flavonoid linarin in rats by inhibiting the P-glycoprotein, and it helps cellular efflux during intestinal absorption [87]. Hence, piperine is called a natural bio-enhancer [88]. Piperine stimulates a dose-dependent increase in the secretion of gastric acid and interruption of gastrointestinal motility [89]. The oral administration of piperine activates the liver, pancreas and digestive enzymes in the small intestinal mucosa [90]. Furthermore, the addition of piperine in food materials as food flavours may increase the protease, lipase, and pancreatic amylase activities [18].

\section{Conclusions}

Based on the reviewed literature, Piper nigrum (L.) has many favourable chemical properties and beneficial effects. Besides, this review presents a summary of the data on the chemical composition of black pepper, including minerals, vitamins, carotenoids and flavonoids, and various therapeutic benefits. Up to date existing information, $>80$ metabolites have been isolated from $P$. nigrum. Among them, biologically active alkaloid piperine and the main essential oils constituents including $\beta$ caryophyllene, limonene, sabinene, $\alpha$-pinene, $\beta$ bisabolene and $\alpha$-copaene can serve as a new natural source for use in food, aroma, cosmetics and pharmaceutical industries. Piperine also has a broad spectrum of therapeutic potential and potential for improving the 
Table 4 Pharmacological activities of Piper nigrum extracts, piperine and BPEO

\begin{tabular}{|c|c|c|c|c|c|c|c|}
\hline $\begin{array}{l}\text { Pharmacological } \\
\text { activities }\end{array}$ & $\begin{array}{l}\text { BPEO/ } \\
\text { Piperine }\end{array}$ & $\begin{array}{l}\text { In } \\
\text { vitro/ } \\
\text { In } \\
\text { vivo }\end{array}$ & Target/ Model & Control(s) & IC 50/Dosage & Results / Remarks & Reference \\
\hline Antioxidant & BPEO & $\begin{array}{l}\ln \\
\text { vitro }\end{array}$ & DPPH scavenging & Not reported & $\begin{array}{l}\mathrm{EC}_{50}: 103.3 \mu \mathrm{g} / \\
\mathrm{ml}\end{array}$ & $\begin{array}{l}\text { Noteworthy radical activity } \\
\text { observed. Though control } \\
\text { details are not reported }\end{array}$ & {$[50]$} \\
\hline Anti-inflammatory & Piperine & $\begin{array}{l}\text { In } \\
\text { vitro }\end{array}$ & B16F-10 melanoma cells & Not reported & $\begin{array}{l}\text { MIC: 2, 5, } 10 \mathrm{mg} / \\
\mu \mathrm{l}\end{array}$ & $\begin{array}{l}\text { Piperine showed dose } \\
\text { dependent inhibition against } \\
\text { B16F-10 melanoma cell lines. } \\
\text { However proper control details } \\
\text { not reported }\end{array}$ & [51] \\
\hline Anti-inflammatory & BPEO & $\begin{array}{l}\text { In } \\
\text { vivo }\end{array}$ & $\begin{array}{l}\text { Carrageenan induced acute } \\
\text { inflammatory Balb/C mice }\end{array}$ & $\begin{array}{l}\text { Positive: } \\
\text { Carrageenan }\end{array}$ & $\begin{array}{l}\text { 100, 500, } \\
1000 \mathrm{mg} / \mathrm{kg} \\
\text { body weight }\end{array}$ & $\begin{array}{l}\text { The dose } 500 \mathrm{mg} / \mathrm{kg} \text { body } \\
\text { weight was performed } \\
\text { significant inhibition ( } 72 \% \text { ) at } \\
\text { 3rd hour compared to control }\end{array}$ & {$[52]$} \\
\hline Anti-inflammatory & BPEO & $\begin{array}{l}\text { In } \\
\text { vivo }\end{array}$ & $\begin{array}{l}\text { Formalin induced chronic } \\
\text { inflammatory Balb/C mice }\end{array}$ & $\begin{array}{l}\text { Positive: } \\
\text { Formalin }\end{array}$ & $\begin{array}{l}\text { 100, 500, } \\
1000 \mathrm{mg} / \mathrm{kg} \\
\text { body weight }\end{array}$ & $\begin{array}{l}500 \mathrm{mg} / \mathrm{kg} \text { body weight BPEO } \\
\text { produced } 50 \% \text { inhibition of } \\
\text { paw edema compared to } \\
\text { control }\end{array}$ & {$[52]$} \\
\hline Anti-inflammatory & BPEO & $\begin{array}{l}\text { In } \\
\text { vivo }\end{array}$ & $\begin{array}{l}\text { Dextran induced acute } \\
\text { inflammatory Balb/C mice }\end{array}$ & $\begin{array}{l}\text { Positive: } \\
\text { Dextran }\end{array}$ & $\begin{array}{l}\text { 100, 500, } \\
1000 \mathrm{mg} / \mathrm{kg} \\
\text { body weight }\end{array}$ & $\begin{array}{l}1000 \mathrm{mg} / \mathrm{kg} \text { body weight } \\
\text { significantly reduced the paw } \\
\text { thickness } 73.4 \% \text { at } 3 \text { rd hour } \\
\text { compared to the control }\end{array}$ & [52] \\
\hline $\begin{array}{l}\text { Antibacterial } \\
\text { activity }\end{array}$ & BPEO & $\begin{array}{l}\text { In } \\
\text { vitro }\end{array}$ & $\begin{array}{l}\text { Alcaligenes faecalis, } \\
\text { Acinetobacter calcoacetica, } \\
\text { Beneckea natriegens, B. subtilis, } \\
\text { Brevibacterium linens, } \\
\text { Clostridium sporogenes, } \\
\text { Citrobacter freundii, E. } \\
\text { carotovora, Enterococcus } \\
\text { faecalis, E. coli, Micrococcus } \\
\text { luteus }\end{array}$ & Not reported & Not reported & $\begin{array}{l}\text { Highest zone of inhibition (19.7 } \\
\text { mm) was obtained against } P \text {. } \\
\text { aeruginosa. However, in this } \\
\text { study dosage and control was } \\
\text { not reported. It reduces } \\
\text { reliability of results }\end{array}$ & [53] \\
\hline Anticancer activity & Piperine & $\begin{array}{l}\text { In } \\
\text { vivo }\end{array}$ & $\begin{array}{l}\text { DMBA induced carcinogenesis } \\
\text { in Syrian golden hamsters }\end{array}$ & $\begin{array}{l}\text { Postive: } \\
\text { DMBA } \\
\text { Negative : } \\
\text { Distilled } \\
\text { water }\end{array}$ & $\begin{array}{l}50 \mathrm{mg} / \mathrm{kg} \text {, oral } \\
\text { administration } \\
\text { for } 14 \text { weeks }\end{array}$ & $\begin{array}{l}\text { Results showed that piperine } \\
\text { totally inhibited the oral } \\
\text { carcinoma formation }\end{array}$ & [20] \\
\hline Anticancer activity & Piperene & $\begin{array}{l}\text { In } \\
\text { vtiro }\end{array}$ & MCF-7 cell line & $\begin{array}{l}\text { Negative : } \\
\text { Distilled } \\
\text { water }\end{array}$ & $\begin{array}{l}\mathrm{IC}_{50}: 1.21 \mu \mathrm{M} \text { for } \\
24 \mathrm{~h} \text { exposure }\end{array}$ & $\begin{array}{l}\text { Piperine exhibited significant } \\
\text { synergistic effects in } \\
\text { combination with paclitaxel on } \\
\text { human breast cancer cell line } \\
\text { MCF-7 }\end{array}$ & {$[54]$} \\
\hline Anticancer activity & Piperene & $\begin{array}{l}\text { In } \\
\text { vtiro }\end{array}$ & $\begin{array}{l}\text { HER overexpressing breast } \\
\text { cancer cell lines (MCF-7 and } \\
\text { SKBR-3) }\end{array}$ & $\begin{array}{l}\text { Negative : } \\
\text { Distilled } \\
\text { water }\end{array}$ & $\begin{array}{l}I_{50}: 200 \mu \mathrm{M} \& \\
50 \mu \mathrm{M} \text { for MCF-7 } \\
\text { and SKBR-3 cell } \\
\text { lines respectively, } \\
48 \mathrm{~h} \text { exposure }\end{array}$ & $\begin{array}{l}\text { Piperine strongly inhibited } \\
\text { proliferation and induced } \\
\text { apoptosis through caspase-3 } \\
\text { activation and PARP cleavage. } \\
\text { Also, piperine inhibited HER2 } \\
\text { gene expression. This study } \\
\text { suggested that piperine may } \\
\text { be a potential agent for the } \\
\text { prevention and treatment of } \\
\text { human breast cancer with } \\
\text { HER2 overexpression }\end{array}$ & {$[55]$} \\
\hline $\begin{array}{l}\text { Antiobesity } \\
\text { activity }\end{array}$ & Piperine & $\begin{array}{l}\text { In } \\
\text { vivo }\end{array}$ & $\begin{array}{l}\text { Obesity-induced dyslipidemia } \\
\text { in high-fat diet rats }\end{array}$ & Not reported & $\begin{array}{l}40 \mathrm{mg} / \mathrm{kg} \text { for } 3 \\
\text { weeks }\end{array}$ & $\begin{array}{l}\text { Supplementation of piperine } \\
\text { with high fat diet significantly } \\
\text { reduced body weight and total } \\
\text { cholesterol. Though control } \\
\text { details not reported }\end{array}$ & {$[56]$} \\
\hline $\begin{array}{l}\text { Antiaging and } \\
\text { wrinkling }\end{array}$ & BPEO & $\begin{array}{l}\text { In } \\
\text { vitro }\end{array}$ & Human neutrophil elastase & $\begin{array}{l}\text { Negative: } \\
\text { Distilled } \\
\text { water }\end{array}$ & $1 \mu \mathrm{g} / \mathrm{ml}$ & $\begin{array}{l}\text { BPEP showed noteworthy } \\
\text { elastase inhibitory activity. } \\
\text { However, dosage of the } \\
\text { experiment is not scientifically } \\
\text { accepted }\end{array}$ & {$[57]$} \\
\hline
\end{tabular}


Table 4 Pharmacological activities of Piper nigrum extracts, piperine and BPEO (Continued)

\begin{tabular}{|c|c|c|c|c|c|c|c|}
\hline $\begin{array}{l}\text { Pharmacological } \\
\text { activities }\end{array}$ & $\begin{array}{l}\text { BPEO/ } \\
\text { Piperine }\end{array}$ & $\begin{array}{l}\text { In } \\
\text { vitro/ } \\
\text { In } \\
\text { vivo }\end{array}$ & Target/ Model & Control(s) & IC 50/Dosage & Results / Remarks & Reference \\
\hline $\begin{array}{l}\text { Antihypertensive } \\
\text { activity }\end{array}$ & Piperine & $\begin{array}{l}\ln \\
\text { vivo }\end{array}$ & $\begin{array}{l}\text { Anesthetize induced Sprague- } \\
\text { Dawley male rats }\end{array}$ & $\begin{array}{l}\text { Positive: } \\
\text { Acetylcholine }\end{array}$ & $\begin{array}{l}1 \text { to } 10 \mathrm{mg} / \mathrm{kg} \\
\text { body weight }\end{array}$ & $\begin{array}{l}\text { Intravenous administration of } \\
\text { piperine caused a dose- } \\
\text { dependent decrease in mean } \\
\text { arterial pressure (MAP) in } \\
\text { normotensive anesthetized rats. } \\
\text { Also, higher dose ( } 30 \mathrm{mg} / \mathrm{kg} \text { ) of } \\
\text { piperine did not cause any fur- } \\
\text { ther change in MAP. However, } \\
\text { this study not reported detailed } \\
\text { dosages along with experiment } \\
\text { duration. }\end{array}$ & {$[19]$} \\
\hline $\begin{array}{l}\text { Antiasthmatic } \\
\text { activity }\end{array}$ & Piperine & $\begin{array}{l}\ln \\
\text { vivo }\end{array}$ & Asthma induced Balb/c mice & $\begin{array}{l}\text { Positive: } \\
\text { Ovalbumin + } \\
\text { vehicle }\end{array}$ & $\begin{array}{l}4.5 \& 2.25 \mathrm{mg} / \mathrm{kg} \text {, } \\
\text { oral } \\
\text { administration, } \\
\text { five times a week } \\
\text { for } 8 \text { weeks }\end{array}$ & $\begin{array}{l}\text { Piperine-treated group had } \\
\text { suppressed eosinophil } \\
\text { infiltration, allergic airway } \\
\text { inflammation and airway hyper } \\
\text { responsiveness, and these } \\
\text { occurred by suppression of the } \\
\text { production of interleukin-4, } \\
\text { interleukin-5, immunoglobulin } \\
\text { E and histamine, than compar- } \\
\text { ing with control group }\end{array}$ & {$[58]$} \\
\hline $\begin{array}{l}\text { Antidepressant \& } \\
\text { cognitive }\end{array}$ & Piperine & $\begin{array}{l}\text { In } \\
\text { vivo }\end{array}$ & Male wistar rats & $\begin{array}{l}\text { Positive: } \\
\text { Diazepam }\end{array}$ & $\begin{array}{l}5,10 \& 20 \mathrm{mg} / \mathrm{kg} \\
\text { body weight } \\
\text { once daily for } 4 \\
\text { weeks }\end{array}$ & $\begin{array}{l}\text { All the treatment showed anti- } \\
\text { depression like activity and } \\
\text { cognitive enhancing activity }\end{array}$ & {$[23]$} \\
\hline $\begin{array}{l}\text { Antidepressant } \\
\text { activity }\end{array}$ & Piperine & $\begin{array}{l}\text { In } \\
\text { vivo }\end{array}$ & $\begin{array}{l}\text { Corticosterone-induced } \\
\text { depression in mice }\end{array}$ & $\begin{array}{l}\text { Negative: } \\
\text { Distilled } \\
\text { water }\end{array}$ & $\begin{array}{l}10 \mathrm{mg} / \mathrm{kg} \text { body } \\
\text { weight for } 24 \mathrm{~h} \text {. }\end{array}$ & $\begin{array}{l}\text { Significant decrease in sucrose } \\
\text { consumption and increase in } \\
\text { immobility time in the forced } \\
\text { swim test and tail suspension } \\
\text { test }\end{array}$ & [59] \\
\hline $\begin{array}{l}\text { Antidepressant } \\
\text { activity }\end{array}$ & Piperine & $\begin{array}{l}\text { In } \\
\text { vivo }\end{array}$ & $\begin{array}{l}\text { Pilocarpine ( } 350 \text { mg/kg i.p.) } \\
\text { induced rats }\end{array}$ & $\begin{array}{l}\text { Positive: } \\
\text { Pilocarpine }\end{array}$ & $\begin{array}{l}25 \mathrm{mg} / \mathrm{kg} \text {, p.o. } \\
\text { for } 10 \text { days }\end{array}$ & $\begin{array}{l}\text { In comparison with pilocarpine, } \\
\text { piperine significantly reduced } \\
\text { lipid peroxidase and catalase } \\
\text { activity, and increased GSH } \\
\text { level, brain-plasma phenytoin } \\
\text { and number of viable neurons }\end{array}$ & [60] \\
\hline $\begin{array}{l}\text { Anticonvulsant } \\
\text { activity }\end{array}$ & Piperine & $\begin{array}{l}\text { In } \\
\text { vivo }\end{array}$ & $\begin{array}{l}\text { Pentylenetetrazole (PTZ)- and } \\
\text { picrotoxin (PIC)-induced } \\
\text { seizure in mice }\end{array}$ & $\begin{array}{l}\text { Negative: } \\
\text { Normal } \\
\text { Saline }\end{array}$ & $\begin{array}{l}30,50 \text { and } \\
70 \mathrm{mg} / \mathrm{kg} \text {, i.p. }\end{array}$ & $\begin{array}{l}\text { Piperine protected animals } \\
\text { from PTZ induced seizures in a } \\
\text { dose-dependent manner. PTZ- } \\
\text { induced convulsion in piperine } \\
\text { treated animals was signifi- } \\
\text { cantly different compared to } \\
\text { saline treated animals }\end{array}$ & {$[61]$} \\
\hline $\begin{array}{l}\text { Insecticidal } \\
\text { activity }\end{array}$ & BPEO & $\begin{array}{l}\text { In } \\
\text { vivo }\end{array}$ & Sitophilus zeamais & $\begin{array}{l}\text { Negative: } \\
\text { Distilled } \\
\text { water }\end{array}$ & $\begin{array}{l}L_{50}: 26.4 \mu \mathrm{l} / \mathrm{g} \\
\text { for } 48 \mathrm{~h}\end{array}$ & $\begin{array}{l}\text { BPEO showed some insecticide } \\
\text { activity (contact toxicity) } \\
\text { against Sitophilus zeamais }\end{array}$ & {$[62]$} \\
\hline
\end{tabular}

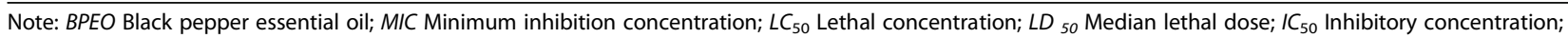
$E C_{50}$ Effective concentration

bioavailability of therapeutic drugs and nutrients. BPEO and piperine have many biological effects such as hepatoprotective, antioxidant, anticancer, antibacterial, antiinflammatory, antifungal, antimicrobial, antihypertensive, antiasthma, antithyroid, wound healing and insecticidal activities. Black pepper has extensive biological effects and has been utilized in preclinical, clinical and therapeutics trials examining novel and new treatments of diseases. Furthermore, piperine and BPEO have been widely explored for their therapeutic potential (Table 4). However, gaps exist in the previous investigations on $P$. nigrum, and we have given suggestions on a few topics that should have priority for detailed examinations.

First, the essential oil of black pepper loses its flavour quickly upon storing under a normal room temperature. However, limited studies have been accompanied on maintaining the shelf life of BPEO. Hence, future research is required to evaluate the storage quality of 


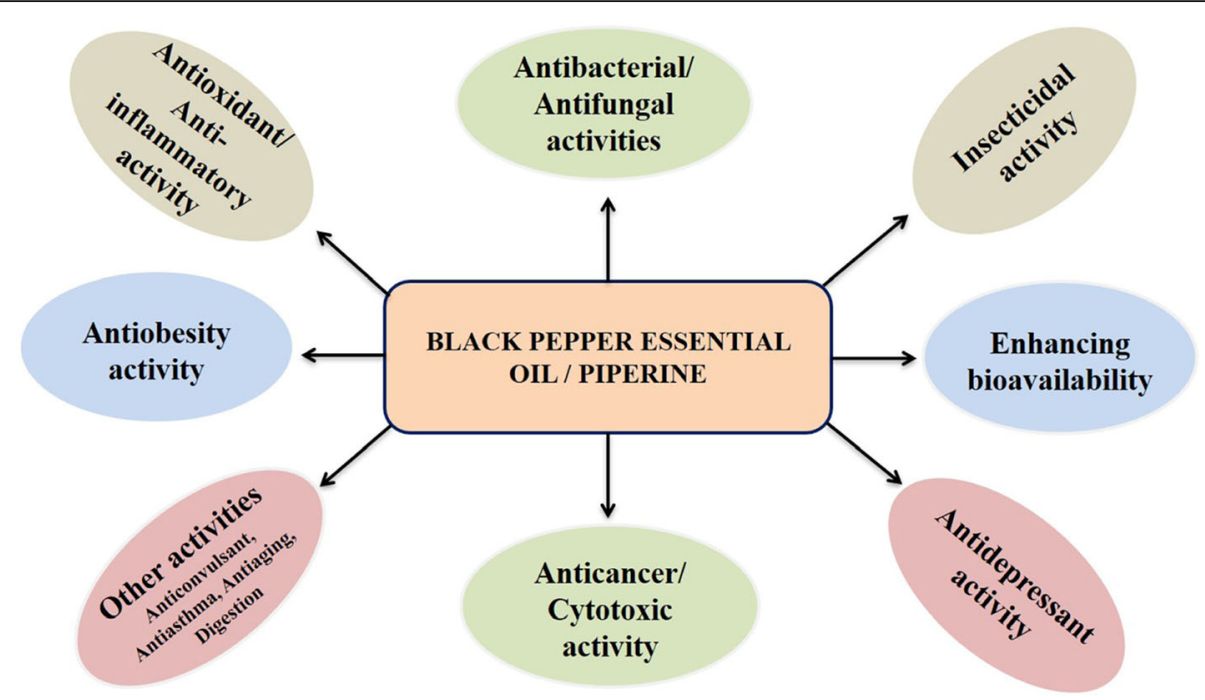

Fig. 3 Diagrammatic representation of black pepper essential oil and piperine potential biological activities

BPEO. Second, insufficient biological and pharmacological investigations have been conducted on piperine and BPEO. A few pharmacological assessments were performed utilizing exceptionally high dosage concentrations, some were inadequate in examination with controls, and others lacked determination of MIC values, perhaps prompting false positive outcomes. Third, even though P. nigrum possesses several potential pharmacological effects on antioxidant, antimicrobial, anticancer, and cytotoxic effects, these studies were employed only in cell lines and animal models, scientific studies in humans have rarely been executed. Hence, the future investigation could focus on the pharmacological properties of piperine, BPEO and active constituents in various clinical studies with humans. Fourth, black pepper-based drugs may be industrialized in future. Future research also needs to conduct clinical trials to investigate the excessive consumption of black pepper in humans and animal models. This review supports the expanded use of black pepper in culinary applications. Regular consumption of black pepper could protect humans from various chronic diseases as a nutraceutical as well as functional food.

\section{Abbreviations}

BPEO: Black pepper essential oil; EO: Essential oils; TNF: Tumour necrosis factor; MIC: Minimum inhibition concentration; LC $C_{50}$ : Lethal concentration; $L_{50}$ : Median lethal dose; $I_{50}$ : Inhibitory concentration; $E_{50}$ : Effective concentration

\section{Acknowledgements}

Not applicable.

\section{Authors' contributions}

KA and MM conceptualized the manuscript. KA wrote the manuscript. MKD and AP collected and reviewed the literature on the chemical composition and biological activities. TW and MM contributed to the manuscript editing. All authors read and approved the final manuscript.

Funding

This work did not receive any funding from an external source.

Availability of data and materials

Not applicable.

\section{Declarations}

Ethics approval and consent to participate

Not applicable.

\section{Consent for publication}

Not applicable.

\section{Competing interests}

The authors declare that they have no competing interests.

\section{Author details}

${ }^{1}$ Cardamom Research Station, Kerala Agricultural University, Pampadumpara, Kerala 685553 Idukki, India. ${ }^{2}$ Department of Biotechnology, PRIST Deemed University, Thanjavur, Tamil Nadu, India. ${ }^{3}$ Department of Plant Sciences,

College of Agriculture and Bioresources, University of Saskatchewan, S7N 5A8 Saskatoon, SK, Canada.

Received: 17 June 2020 Accepted: 4 June 2021

Published online: 09 June 2021

\section{References}

1. Nair KP. Agronomy and economy of black pepper and cardamom. The King and Queen of Spices: Elsevier press; 2011. p.380.

2. Damanhouri ZA, Ahmad A. A review on therapeutic potential of Piper nigrum L. (Black Pepper): the king of spices. Med Aromat Plants. 2014;3:161. doi:https://doi.org/10.4172/2167-0412.1000161.

3. Raja BP, Sethuraman MG. Inhibitive effect of black pepper extract on the sulphuric acid corrosion of mild steel. Mater Lett. 2008:62:2977-9.

4. Ashokkumar K, Kumarakurubaran S, Saradha Devi SM. Reverse phase-high performance liquid chromatography-diode array detector (RP-HPLC-DAD) analysis of flavonoids profile from curry leaf (Murraya koenigii. L). J Med Plants Res. 2013;7:3393-9.

5. Muthukrishnan SD, Ashokkumar K, Annapoorani S. Identification and determination of flavonoids, carotenoids and chlorophyll concentration in Cynodon dactylon (L.) by HPLC analysis. Nat Prod Res. 2014;29:785-90. 
6. Ashokkumar K, Arjun P, Murugan M, Dhanya MK, Sathyan T, Sivakumar P, Surya R. Simple and rapid extraction method for determination of carotenoids in the edible parts of Vitis vinifera, Vaccinum sect. cyanococcus, Ipomoea batatas and Capsicum annum. Adv Res. 2018;17(4):1-8. https://doi. org/10.9734/AIR/2018/45132.

7. Ashokkumar K, Tar'an B, Diapari M, Arganos G, Warkentin TD. Effect of cultivar and environment on carotenoid profile of pea and chickpea. Crop Sci. 2014:54:2225-35.

8. Ashokkumar K, Diapari M, Jha AB, Tar'an B, Arganosa G, Warkentin TD. Genetic diversity of nutritionally important carotenoids in 94 pea and 121 chickpea accessions. J Food Compos Anal. 2015;43:49-60. https://doi.org/1 0.1016/j.jfca.2015.04.014.

9. Ashokkumar K, Murugan M, Dhanya MK, Surya R, Kamaraj D. Phytochemical variations among four distinct varieties of Indian cardamom Elettaria cardamomum (L.) Maton. Nat Prod Res. 2020;34(13):1919-22. https://doi. org/10.1080/14786419.2018.1561687.

10. Ashokkumar K, Pandian A, Murugan M, Dhanya MK, Sathyan T, Sivakumar P, Surya R. Warkentin TD. Profiling bioactive flavonoids and carotenoids in select south Indian spices and nuts. Nat Prod Res. 2020;34(9):1306-10.

11. Zou L, Hu YY, Chen WX. Antibacterial mechanism and activities of black pepper chloroform extract. J Food Sci Technol. 2015;52:8196-203.

12. Pan $Y$, Zhu Z, Huang Z, Wang $H$, Liang $Y$, Wang $K$, Lei Q, Liang $M$. Characterisation and free radical scavenging activities of novel red pigment from Osmanthus fragrans' seeds. Food Chem. 2009;112:909-13.

13. Wong CM, Ling JJ. In Vitro Study of Wound Healing Potential in Black Pepper (Piper nigrum L.). UK J Pharmaceut Biosci. 2014;2:05-9.

14. Gülçin I. The antioxidant and radical scavenging activities of black pepper (Piper nigrum) seeds. Int J Food Sci Nutr. 2005;56:491-9.

15. McNamara FN, Randall A, Gunthorpe MJ. Effects of piperine, the pungent component of black pepper, at the human vanilloid receptor (TRPV1). Br J Pharmacol. 2005;144:781-90.

16. Vasudevan K, Vembar S, Veeraraghavan K, Haranath PS. Influence of intragastric perfusion of aqueous spice extracts on acid secretion in anesthetized albino rats. Ind J Gastroenterol. 2000;19:53-6.

17. Szallasi A. Piperine. Researchers discover new flavor in an ancient spice. Trends Pharmacol Sci. 2005:26:437-9.

18. Srinivasan K. Black pepper and its pungent principle-piperine: a review of diverse physiological effects. Crit Rev Food Sci Nutr. 2007;47:735-48.

19. Taqvi SI, Shah AJ, Gilani AH. Blood pressure lowering and vasomodulator effects of piperine. J Cardiovasc Pharmacol. 2008;52:452-8.

20. Manoharan S, Balakrishnan S, Menon V, Alias L, Reena A. Chemopreventive efficacy of curcumin and piperine during 7,12-dimethylbenz[a] anthraceneinduced hamster buccal pouch carcinogenesis. Singapore Med J. 2009;50: 139-46.

21. Li S, Wang C, Wang M, Li W, Matsumoto K, Tang Y. Antidepressant like effects of piperine in chronic mild stress treated mice and its possible mechanisms. Life Sci. 2007;80:1373-81.

22. Johnson JJ, Nihal M, Siddiqui IA, Scarlett CO, Bailey HH, Mukhtar H. Ahmad $\mathrm{N}$ Enhancing the bioavailability of resveratrol by combining it with piperine. Mol Nutr Food Res. 2011;55:1169-76.

23. Wattanathorn J, Chonpathompikunlert P, Muchimapura S, Priprem A, Tankamnerdthai O. Piperine, the potential functional food for mood and cognitive disorders. Food Chem Toxicol. 2008;46:3106-10.

24. Peter KV. Handbook of herbs and spices. Sawston: Woodhead Publishing; 2006. p. 640.

25. Peter KV. Futurology of black pepper. In: Ravindran PN, editor. Black Pepper (Piper nigrum L.). Amsterdam: Harwood Academic; 2000. pp. 481-7.

26. Parthasarathy VA, Chempakam B, Zachariah TJ. Chemistry of spices. London: CAB International; 2008. p.464.

27. Scott IM, Gagnon N, Lesage L, Philogène BJ, Arnason JT. Efficacy of botanical insecticides from Piper species (Piperaceae) extracts for control of European chafer (Coleoptera: Scarabaeidae). J Econ Entomol. 2005;98:84555.

28. Naseem MT, Khan RR. Comparison of repellency of essential oils against red flour beetle Tribolium castaneum Herbst (Coleoptera: Tenebrionidae). J Stored Prod Postharvest Res. 2011;2:131-5.

29. Jayalekshmy A, Menon AN, Padmakumari KP. Essential oil composition of four major cultivars of black pepper (Piper nigrum L.). J Essent Oil Res. 2003; 15:155-7.

30. Jose J, Sharma AK. Chromosome studies in the genus Piper L. J Indian Bot Soc. $198 ; 63: 313-319$.
31. Ravindran PN. (1990). Studies on black pepper and some of its wild relatives. Ph. D Thesis. Univ. Calicut, Kerala, India.

32. Purseglove JW, Brown EG, Green CL, Robbins SRJ. Pepper. Spices. Vol. 1. Longman, London; 1981. pp. 10-99.

33. Chandy KC, Pillai VS. Functional differentiation in the shoot system of pepper (Piper nigrum L.). Ind Spices. 1979;16:8-12.

34. Parthasarathy VA, Sasikumar B, Nair RR, George KJ. Black Pepper: Botany and Horticulture. In; Hort Rev. 2007;33:173-266.

35. Sasikumar B, George JK, Ravindran PN. Breeding behaviour of black pepper (Piper nigrum L.). Indian J Genet. 1992;52:17-21.

36. Tainter DR, Grenis AT. Spices and Seasonings. A Food Technology Handbook. 2nd ed. New York: Wiley-VCH; 2001. p. 256.

37. Nwofia GE, Kelechukwu C, Nwofia BK. Nutritional composition of some Piper nigrum (L.) accessions from Nigeria. Int J Med Arom Plants. 2013;3:247-54.

38. Sruthi D, Zachariah TJ, Leela NK, Jayarajan K. Correlation between chemical profiles of black pepper (Piper nigrum L.) var. Panniyur-1 collected from different locations. J Med Plants Res. 2013;7:2349-57.

39. Kurian PS, Backiyarani S, Josephrajkumar A, Murugan M. Varietal evaluation of black pepper (Piper nigrum L.) for yield, quality and anthracnose disease resistance in Idukki District, Kerala. J Spices Aromat Crops. 2002;11:122-4.

40. Rmili R, Ramdani M, Ghazi Z, Saidi N, El Mahi B. Composition comparison of essential oils extracted by hydrodistillation and microwave-assisted hydrodistillation from Piper nigrum L. J Mater Environ Sci. 2014;5:1560-7.

41. Utpala P, Asish GR, Zachariah TJ, Saji KV, George JK, Jayarajan K, Mathew PA, Parthasarathy VA. Spatial influence on the important volatile oils of Piper nigrum leaves. Cur Sci. 2008;94:1632-5.

42. Hussain MDS, Hegde L, Goudar SA, Hegde NK, Shantappa T, Gurumurthy SB, Manju MJ, Shivakumar KM. Evaluation of local black pepper (Piper nigrum L.) genotypes for yield and quality under arecanut based cropping system. Int J Pure App Biosci. 2017;5:1396-400.

43. Yu GW, Cheng Q, Nie J, Wang P, Wang XJ, Li ZG, Leec MR. DES-based microwave hydrodistillation coupled with GC-MS for analysis of essential oil from black pepper (Piper nigrum) and white pepper. Anal Methods. 2017;9: 6777-84.

44. Kumoro AC, Hasan M, Singh $H$. Extraction of Sarawak black pepper essential oil using supercritical carbon dioxide. Arab J Sci Eng. 2010;35:7-16.

45. Aziz S, Naher S, Abukawsar MD, Roy SK. Comparative studies on physicochemical properties and gc-ms analysis of essential oil of the twovarieties of the black pepper (Piper nigrum Linn.). Int J Pharm Phytopharmacol Res. 2012;2:67-70.

46. Nikolić M, Stojković D, Glamočlija J, Ćirić A, Marković T, Smiljković M, Soković M. Could essential oils of green and black pepper be used as food preservatives? J Food Sci Technol. 2015;52:6565-73.

47. Packiyasothy EV, Balachandran S, Jansz ER. Effect of storage (in small packages) on volatile oil and piperine content of ground black pepper. J Natn Sci Coun Sri Lanka. 1983;11:111-22.

48. Orav A, Stulova I, Kailas T, Müürisepp M. Effect of storage on the essential oil composition of Piper nigrum L. fruits of different ripening states. J Agric Food Chem. 2004:52:2582-6.

49. Silva AG, Almeida DL, Ronchi SN, Bento AC, Scherer R, Ramos A, Cruz ZMA. The essential oil of Brazilian pepper, Schinus terebinthifolia Raddi in larval control of Stegomyia aegypti (Linnaeus, 1762). Parasit Vectors. 2010;3:79. doi: https://doi.org/10.1186/1756-3305-3-79.

50. Bagheri H, Bin Abdul Manap MY, Solati Z. Antioxidant activity of Piper nigrum L. essential oil extracted by supercritical $\mathrm{CO}_{2}$ extraction and hydrodistillation. Talanta. 2014;121:220-8.

51. Pradeep CR, Kuttan G. Piperine is a potent anticancer of nuclear factorkappaB (NF-KappaB), c-Fos, CREB, ATF-2 and proinflammatory cytokine gene expression in B16F-10 melanoma cells. Int Immunopharmacol. 2004;4:1795803.

52. Jeena K, Liju VB, Umadevi NP, Kuttan R. Antioxidant, anti-inflammatory and antinociceptive properties of black pepper essential oil (Piper nigrum Linn). J Essential Oil Bearing Plants. 2014;17:1-12.

53. Dorman HJD, Deans SG. Antimicrobial agents from plants: Antibacterial activity of plant volatile oils. J Appl Microbiol. 2000;88:308-16.

54. Motiwala MN, Rangari VD. Combined effect of paclitaxel and Piperine on a MCF-7 breast cancer cell line in vitro: Evidence of a synergistic interaction. Synergy. 2015;2:1-6.

55. Do MT, Kim HG, Choi JH, Khanal T, Park BH, Tran TP, Jeong TC, Jeong HG. Antitumor efficacy of Piperine in the treatment of human HER2overexpressing breast cancer cells. Food Chem. 2013;141:2591-9. 
56. Shah SS, Shah GB, Singh SD, Gohil PV, Chauhan K, Shah KA, Chorawala M. Effect of piperine in the regulation of obesity-induced dyslipidemia in highfat diet rats. Indian J Pharmacol. 2011;43:296-9.

57. Mori M, Ikeda N, Kato Y, Minamino M, Watabe K. Inhibition of elastase activity by essential oils in vitro. J Cosmet Dermatol. 2003;1:183-7.

58. Kim SH, Lee YC. Piperine inhibits eosinophil infiltration and airway hyper responsiveness by suppressing $T$ cell activity and Th2 cytokine production in the ovalbumin-induced asthma model. J Pharm Pharmacol. 2009;61:3539.

59. Mao QQ, Huang Z, Zhong XM, Xian YF, Ip SP. Piperine reverses the effects of corticosterone on behavior and hippocampal BDNF expression in mice. Neurochem Int. 2014;74:36-41.

60. Pany S, Abhisek P, Pratap KS. Potential neuroprotective effect of Piperine in pilocarpine induced temporal lobe epilepsy. Am J Pharm Res. 2016;6:436975.

61. Bukhari IA, Pivac N, Alhumayyd MS, Mahesar AL, Gilani AH. The analgesic and anticonvulsant effects of piperine in mice. J Physiol Pharmacol. 2013;64 789-94

62. Chaubey MK. Evaluation of insecticidal properties of Cuminum cyminum and Piper nigrum Essential Oils against Sitophilus zeamais. J Entomol. 2017;14: $148-54$.

63. Metodiewa D, Koska C. Reactive oxygen species and reactive nitrogen species: relevance to cyto (neuro) toxic events and neurologic disorders an overview. Neurotox Res. 2000;1:197-233.

64. Halliwell B. The antioxidant paradox. Lancet. 2000;355:1179-80.

65. Echeverría F, Ortiz M, Valenzuela R, Videla LA. Hydroxytyrosol and Cytoprotection: A Projection for Clinical Interventions. Int J Mol Sci. 2017; 18(5):930. doi:https://doi.org/10.3390/ijms18050930.

66. Valenzuela R, Illesca P, Echeverría F, Espinosa A, Rincón-Cervera M, Ortiz M, Hernandez-Rodas MC, Valenzuela A, Videla LA. Molecular adaptations underlying the beneficial effects of hydroxytyrosol in the pathogenic alterations induced by a high-fat diet in mouse liver: PPAR- $a$ and Nrf2 activation, and NF-kB down-regulation. Food Funct. 2017:8(4):1526-37. doi: https://doi.org/10.1039/c7fo00090a.

67. Illesca P, Valenzuela R, Espinosa A, Echeverría F, Soto-Alarcon S, Ortiz M, Videla LA. Hydroxytyrosol supplementation ameliorates the metabolic disturbances in white adipose tissue from mice fed a high-fat diet through recovery of transcription factors Nrf2, SREBP-1C, PPAR- $\gamma$ and NF-KB. Biomed Pharmacother. 2019;109:2472-81. doi:https://doi.org/10.1016/j.biopha.201 8.11.120.

68. Vijayakumar RS, Surya D, Nalini N. Antioxidant efficacy of black pepper (Piper nigrum L.) and piperine in rats with high fat diet induced oxidative stress. Redox Rep. 2004;9:105-10.

69. Zarai Z, Boujelbene E, Salem NB, Gargouri Y, Sayari A. Antioxidant and antimicrobial activities of various solvent extracts piperine and piperic acid from Piper nigrum. LWT-Food Sci Technol. 2013;50:634-41.

70. Kito M, Takimoto $R$, Onji Y, Yoshida T, Nagasawa T. Purification and characterization of an $\varepsilon$-poly-l-lysine-degrading enzyme from the $\varepsilon$-poly-llysine-tolerant Chryseobacterium sp. OJ7. J Biosci Bioeng. 2003;96:92-4.

71. Rani SKS, Saxena N, Udaysree. Antimicrobial activity of black pepper (Piper nigrum L.). Global J Pharmacol. 2013;7:87-90.

72. Pradhan KJ, Variyar PS, Bandekar JR. Antimicrobial activity of novel phenolic compounds from green pepper (Piper nigrum L.). LWT-Food Sci Technol. 1999;32:121-3.

73. Karsha PV, Lakshmi OB. Antibacterial activity of black pepper (Piper nigrum Linn.) with special reference to its mode of action of bacteria. Indian J Nat Prod Resources. 2010;1:213-5.

74. Zhang J, Ye KP, Zhang X, Pan DD, Sun YY, Cao JX. Antibacterial activity and mechanism of action of black pepper essential oil on meat-borne Escherichia coli. Front Microbiol. 2017;7:2094. doi:https://doi.org/10.3389/ fmicb.2016.02094.

75. Morsy NFS, Abd El-Salam EA. Antimicrobial and antiproliferative activities of black pepper (Piper nigrum L.) essential oil and oleoresin. J Essential Oil Bearing Plants. 2017;20:779-90.

76. Patil NN, Patel SB. Evaluation of antimicrobial activity of neem and black pepper extracts and its efficacy in decontaminating Gutta percha cones. Int Res J Biological Sci. 2017;6(8):7-16.

77. Kavitha S, Mani P. Antibacterial activity of extract of Piper nigrum leaf. Biotechnol Ind J. 2017;13:144.

78. Van Vuuren SF. Antimicrobial activity of South African medicinal plants. J Ethnopharmacol. 2008;119:462-72.
79. Samykutty A, Shetty AV, Dakshinamoorthy G, Bartik MM, Johnson GL, Webb B, Zheng G, Chen AX, Kalyanasundaram RS, Munirathinam G. Piperine, a bioactive component of pepper spice exerts therapeutic effects on androgen dependent and androgen independent prostate cancer cells. PLoS One. 2013;8(6):e65889.

80. Makhov P, Golovine K, Canter D, Kutikov A, Simhan J, Corlew MM, Uzzo RG, Kolenko VM. Co-administration of piperine and docetaxel results in improved antitumor efficacy via inhibition of CYP3A4 activity. Prostate. 2012 72:661-7.

81. Zhang J, Zhu X, Li H, Li B, Sun L, Xie T, Zhu T, Zhou H, Ye Z. Piperine inhibits proliferation of human osteosarcoma cells via G2/M phase arrest and metastasis by suppressing MMP-2/-9 expression. Int Immunopharmacol. 2015:24:50-8.

82. De Souza GVM, Kviecinski MR, Santos MNS, Ourique F, Castro LSPW, Andreguetti RR, Correia JFG, Filho DW, Pich CT, Pedrosa RC. Piper nigrum ethanolic extract rich in piperamides causes ROS over production, oxidative damage in DNA leading to cell cycle arrest and apoptosis in cancer cells. J Ethnopharmacol. 2016;189:139-47.

83. Mona AM, Abo-Zeid, Farghaly AA. The antimutagenic activity of piperine against mitomycine $\mathrm{C}$ induced sister chromatid exchange and chromosomal aberrations in Mice. Nat Sci. 2009;7:72-8.

84. Abdelhamed S, Yokoyama S, Refaat A, Ogura K, Yagita H, Awale S, Saiki I. Piperine enhances the efficacy of TRAlL-based therapy for triple-negative breast cancer cells. Anticancer Res. 2014;34:1893-9.

85. Greenshields AL, Doucette CD, Sutton KM, Madera L, Annan H, Yaffe PB, Knickle AF, Dong ZM, Hoskin DW. Piperine inhibits the growth and motility of triple-negative breast cancer cells. Cancer Lett. 2015;357:129-40.

86. Upadhyay RK, Jaiswal G. Evaluation of biological activities of Piper nigrum oil against Tribolium castaneum. Bull Insectol. 2007;60:57-61.

87. Feng $X$, Liu $Y$, Wang $X$, Di X. Effects of piperine on the intestinal permeability and Pharmacokinetics of Linarin in Rats. Molecules. 2014;19: 5624-33.

88. Dudhatra GB, Mody SK, Awale MM, Patel HB, Modi CM, Kumar A, Kamani DR, Chauhan BN. A comprehensive review on pharmacotherapeutics of herbal bioenhancers. Sci World J. 2012;2012:637953.

89. Han HK. The effects of black pepper on the intestinal absorption and hepatic metabolism of drugs. Expert Opin Drug Metab Toxicol. 2011;7:7219.

90. Awen BZ, Ganapati S, Chandu BR. Influence of sapindus mukorossi on the permeability of ethyl cellulose free film for transdermal use. Res J Pharma Biol Chem Sci. 2010;1:35-8.

\section{Publisher's Note}

Springer Nature remains neutral with regard to jurisdictional claims in published maps and institutional affiliations.

\section{Submit your manuscript to a SpringerOpen ${ }^{\circ}$ journal and benefit from:}

- Convenient online submission

- Rigorous peer review

- Open access: articles freely available online

- High visibility within the field

- Retaining the copyright to your article

Submit your next manuscript at $>$ springeropen.com 